\title{
Perceived causes of students' low enrolment in science in secondary schools, Nigeria
}

\author{
Aina, Jacob Kola ${ }^{1}$, Adedo Ganiyu Akanbi ${ }^{2}$ \\ ${ }^{1}$ Physics Department College of Education (T) Lafiagi, Kwara State, Nigeria \\ ${ }^{2}$ Chemistry Department College of Education (T) Lafiagi, Kwara State, Nigeria
}

\section{Email address:}

akoja64@gmail.com(Aina, Jacob Kola)

\section{To cite this article:}

Aina, Jacob Kola, Adedo Ganiyu Akanbi. Perceived Causes of Students' Low Enrolment in Science in Secondary Schools, Nigeria. International Journal of Secondary Education. Vol. 1, No. 5, 2013, pp. 18-22. doi: 10.11648/j.ijsedu.20130105.11

\begin{abstract}
The paper sampled 80 secondary school students in a local government council to find out causes of student low enrolment in science in secondary schools. The paper highlighted the history of science teaching and teacher's pedagogy of teaching in Nigeria as very germane to enrolment in schools. Questionnaire was used to sample students' opinion on causes of low enrolment. Statistical analysis considered best for this study was frequency count and percentage. Findings revealed that lack of qualified science teachers, lack of instructional materials, subject nature, low student interest and lack of motivation among others causes low enrolment in science. Some recommendations were suggested at the end of the study.
\end{abstract}

Keywords: Enrolment, Pedagogy of Teaching, Scientific Inquiry, Memorization, Rote Learning

\section{Introduction}

There has been continuous decline in science enrolment in Nigeria school especially in secondary schools. [4] and [13] observed low enrolment of students in science subjects and called for investigation. Considering vital role science plays in technological development of a nation the study is very relevant at this time. According to [8], science education can offer solutions to many of the technological problems facing the country.

The study employed descriptive survey method of research where students' opinions were sampled using questionnaire. Questionnaire containing 20 items which was validated by a senior lecturer in school of science in a college of education was used as an instrument for the study.

The purpose of the study was to find out causes of low enrolment among secondary school students in Nigeria schools. The study could be of great importance to the development of science education in the country.

Statistical analysis considered suitable for this study is frequency count and percentages because according to [19], it is used for organizing and describing the characteristics of educational variables in a simple and meaningful way.

The four research questions that will guide this study are:

1. Can science teacher in any way cause students' low enrolment of science in secondary schools?

2. Do science instructional materials cause students' low science enrolment in secondary schools?

3. Could the nature of science subjects cause students' low science enrolment in secondary schools?

4. Do interest and motivation have any effect on students' enrolment of science in secondary schools?

There are two fundamentals issues that are very germane to this study and that must not be overlooked; they are historical development of science teaching and pedagogy of science teaching in secondary schools in Nigeria.

\subsection{Historical Development of Science Teaching in Nigeria Secondary Schools}

The roles of various professional bodies like the West African Examinations Council (WAEC), Science Teachers Association of Nigeria (STAN), Comparative Education Study Adaptation Center (CESAC) and many others cannot be forgotten in the development of science education in Nigerian. Missionaries who brought formal education into Nigeria came with general or nature science that does not suit our location in Nigeria. The teaching of science was only done with foreign illustrations which cannot help scientific inquiry for Nigerian students. Science was learnt by memorization and rote learning.

The coming together of professional bodies like STAN 
and WAEC lead to curriculum formation body like CESAC, who struggled for the formulation of a new curriculum that suit Nigerian purpose. History tells us that before 1859 no meaningful science was taught in Nigerian secondary schools [18].

Curriculum development conferences and workshop were held between 1969 and 1975 resulting into production of science curriculum materials for both primary and secondary levels and the national policy on education document [18].

Science teaching in Nigerian schools was not very serious and meaningful before 1930; it was just only writing subjects like biology, chemistry and physics etc on the school timetable without trained teachers to teach the subjects [1].

School Certificate Examination started in 1928 moderated by Oxford and Cambridge Local Examination Boards. The teaching of science by this time was not uniformed in schools because of lack of trained science teachers; science was taught as General Science comprising biology, chemistry and physics. By the time Oxford and Cambridge served as moderators for Nigerian, science syllabus was reflecting British requirement and aspirations rather than Nigerian's own [1]. Most teaching in science was beyond Nigerian students experience because its content and activities were foreign to them. Changes in contents and science activities began to reflect the need of Nigerian since 1950 when WAEC was established and took over from Cambridge School Certificate Examination Board.

In 1957 STAN was inaugurated to popularized science in schools. There were lots of developments in science education in Nigeria from the time of establishment of WAEC and inauguration of STAN.

In 1968 STAN in collaboration with Federal Ministry of Education and CESAC set up Curriculum Development Committee in biology, chemistry and physics. The committee in response to the aspiration and yearning of Nigerians for meaningful science teaching called for the Curriculum Conference of 1969 after the independent.

In 1970 and 1971 projects for each of the subject were formed called the Nigerian Secondary Schools Science Project (NSSSP) and the Nigerian Integrated Science Project (NISP).

The development, implementation and evaluation of NSSSP produced very good result in the history of science teaching in Nigeria [9]. There have been changes in the organization of science content in secondary school level as a result of these projects.

\subsection{The Pedagogy of Science Teaching}

Here we look at teaching in science education classes: we consider the art of teaching in science. Nigerian science teachers are still very far behind their counterpart in the world. The percentage of science teachers who are computer literate is still low, not even talk of being able to manipulate computer to teach in classroom situation. Teaching in the world today has gone beyond talk and chalk method, therefore teacher should be able to use different strategies as there are no single universal approach for specific class [16].

Science teacher should understand that science education is a content specific learning and this should guide the teacher as he taught student any module of the content in class [14]. The problem at hand in Nigeria is very serious: an engineer teaching physics in school may not teach the entire module because he or she may not know the approach to the content. For instance, engineer might concentrates on calculation aspect of the content at the detriment of other content of the module. This cannot help the student, there are many unqualified science teachers in Nigeria school as confirm by [10] on his study of challenges and prospects of primary science teaching. This set of teachers may have the good mastery of the subject but understanding his or her audience (student) psychologically and socially is very important before learning could take place.

The world is talking about integrating technology into classroom situation now: the implication of it is that all teachers must be sound in computer and have personal computer. In Nigeria today less than $50 \%$ of science teachers are computer literate and out of this percentage less than $30 \%$ of them do not have their personal computer [10].

Science teaching should not only be until when teacher is in the classroom with students; science could be taught through e-mail, blog and mobile devices. This could only be possible if teachers and student have e-mail address and personal blog. Many teachers do not have e-mail address because they do not know its importance. In developed world, teacher post learning activities on his or her website and student go there to access it without teacher being in class. Colllis and Moones in [17] classified application of ICTs into classroom teaching, the learning resources, instructional organization of learning and communication. This made use of educational software, computer-based testing system, e-mail system among others.

In Nigeria of today very few schools including universities can be proud of using any of the above mentioned ICTs in science classes adequately. Except we deceive ourselves science pedagogy in Nigerian have problem. Teachers play a unique role in improving students' achievement in science [15].

\section{Methodology}

Table 1: Teacher

\begin{tabular}{lcccc}
\hline \multicolumn{5}{c}{ Responses } \\
\multicolumn{1}{c}{ item } & Yes & \% & No & \% \\
\hline $\begin{array}{l}\text { No qualified science } \\
\text { teachers }\end{array}$ & 55 & 68.75 & 25 & 31.25 \\
$\begin{array}{l}\text { Teachers are not } \\
\text { teaching well }\end{array}$ & 41 & 51.25 & 37 & 48.75 \\
\hline
\end{tabular}


Table 2: Instructional materials

\begin{tabular}{lcccc}
\hline \multicolumn{1}{c}{ Responses } & & & \\
\multicolumn{1}{c}{ item } & Yes & \% & No & \% \\
\hline & 50 & 60.5 & 30 & 37.5 \\
No enough science equipment & 30 & 37.5 & 50 & 62.5 \\
No good science laboratory & 48 & 60 & 32 & 40 \\
$\begin{array}{l}\text { Science textbooks are difficult } \\
\text { to understand }\end{array}$ & & & & \\
\hline
\end{tabular}

Table 3: Subject nature

\begin{tabular}{lcccc}
\hline & $\begin{array}{c}\text { Responses } \\
\text { Yes }\end{array}$ & \% & No & \% \\
\hline $\begin{array}{l}\text { Science subjects are too } \\
\text { difficult to learn }\end{array}$ & 47 & 58.75 & 33 & 41.25 \\
$\begin{array}{l}\text { Physics is too abstract } \\
\text { Biology is too wide in } \\
\text { scope }\end{array}$ & 42 & 52.50 & 38 & 47.50 \\
$\begin{array}{l}\text { Chemistry is very hard to } \\
\text { learn } \\
\text { Science is too } \\
\text { mathematical }\end{array}$ & 41 & 51.25 & 39 & 48.75 \\
\hline
\end{tabular}

Table 4: Interest/ motivation

\begin{tabular}{|c|c|c|c|c|}
\hline \multicolumn{5}{|c|}{ Responses } \\
\hline item & Yes & $\%$ & No & $\%$ \\
\hline Students don't have interest & 62 & 77.50 & 18 & 22.50 \\
\hline No parental influence & 44 & 55.00 & 36 & 45.00 \\
\hline Lack of peer influence & 42 & 52.50 & 38 & 47.50 \\
\hline Lack of motivation & 40 & 50.00 & 40 & 50.00 \\
\hline
\end{tabular}

Table 5: Others

\begin{tabular}{lcccc}
\hline \multicolumn{1}{c}{ Item } & Yesponses & & & \\
\multicolumn{1}{c}{} & Yes & \% & No & \% \\
\hline & 47 & 58.75 & 33 & 41.25 \\
$\begin{array}{l}\text { Poor primary school } \\
\text { background }\end{array}$ & 45 & 56.25 & 35 & 43.75 \\
$\begin{array}{l}\text { Science involves huge money } \\
\text { Low career opportunity in }\end{array}$ & 43 & 53.75 & 37 & 46.25 \\
$\begin{array}{l}\text { science } \\
\text { Science is for brilliant } \\
\text { students }\end{array}$ & 52 & 65.00 & 28 & 35.00 \\
$\begin{array}{l}\text { Science is very risky } \\
\text { Too much time for experiment }\end{array}$ & 52 & 65.00 & 28 & 35.00 \\
\hline
\end{tabular}

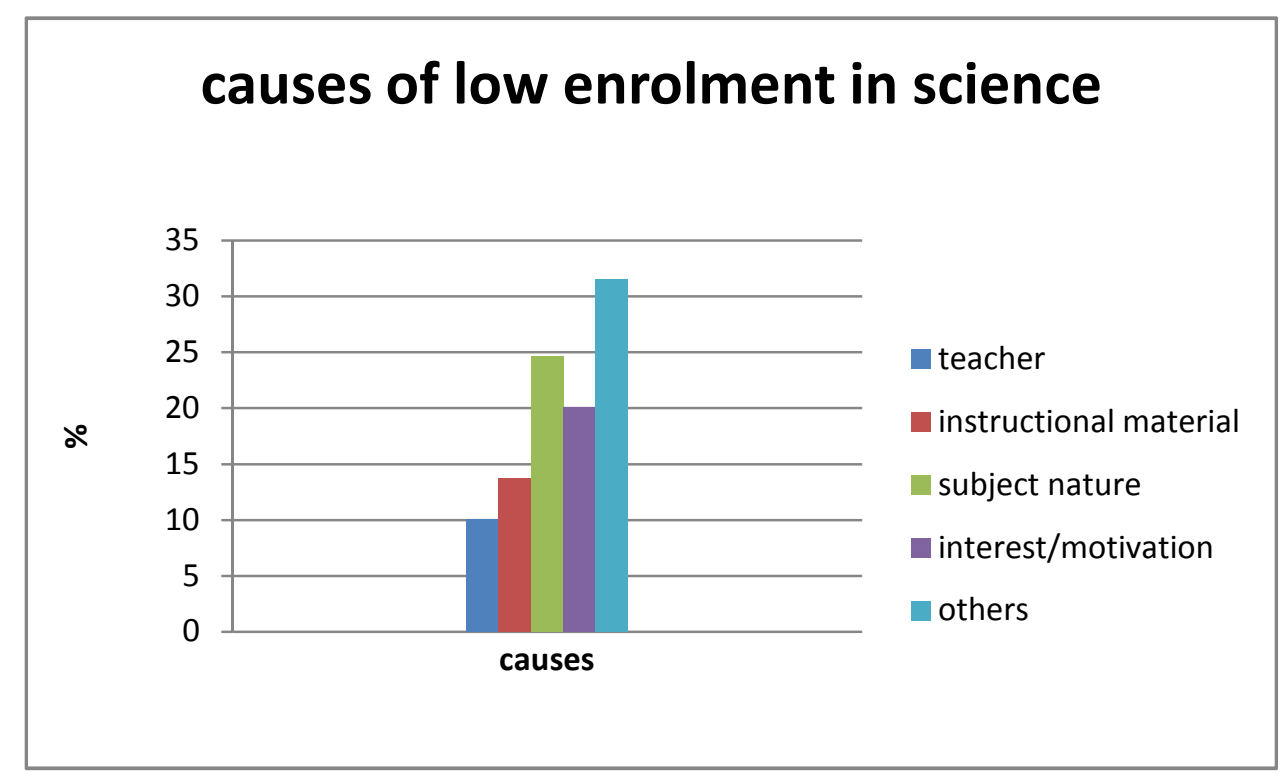

Chart 1: Causes of low enrolment in science

\section{Findings}

From table 1 above it was revealed that, there were lacks of qualified science teachers in the sampled secondary schools; $52.25 \%$ of the respondents in these schools also indicated that science teachers were not teaching well. This answered research question 1 .

Inference from table 2 could be drawn that there is no enough science teaching equipment in this schools; students of these school also indicated that science textbooks were difficult to understand; therefore research question 2 is hereby answered.

Table three clearly shows that the nature of science causes low enrolment in science. Physics is too abstract: biology is too wide in scope: chemistry is very hard to learn and science is too mathematical; this also answered research question 3 .

Observation from table 4 reveals students lack of interest in science: no influences from both parents and peer for student to enroll in science; $50 \%$ of the students also lack motivation and this answered research question 4 . 
Poor background of students' in primary science: huge financial involvement in science: low career opportunity; feeling that science is only for the brilliant students: science is very risky and too much time for experiment were shown in table 5 as perceived causes of students' low enrolment in science.

From chart 1 above apart from other causes, subject nature took the highest percentage of causes of science low enrolment in secondary schools followed by interest; teachers' factor had the lowest percentage.

\section{Discussion}

Teacher is very important in the process of teaching and learning of any subject in school including science subject; that is why teacher must be well qualified and teach very well in schools. To this end teacher must be properly trained because their output will surely go a long way to influence their students, which is why [22] said the quality of teacher depends upon their training and preparation. The finding of this study agreed with [11] that there were lack of qualified science teachers to teach science in primary schools.

Teachers' method of teaching is very important in teaching and learning process, that is why for any teacher to teach well he or she should be able to use appropriate method of teaching at the appropriate time and lesson.

Where teachers are not teaching very well either by not using good method or not committed to his or her duty students will lose interest in such teacher and in the subject.

For students to learn very well and create interest in science it must be taught with good instructional materials. This aid the teacher from teaching and also students to learn as confirmed by [10] that instructional materials are very important in teaching and learning science if adequately used. Where these are absent it will affect students' performance and eventually reduce enrolment in science.

Science subject like physics is regarded as an abstract subject by [18] is confirmed by this study. This study also agreed with [12] that physics is a calculation oriented subject and positively correlated to mathematics. Students who are not very good in mathematics may find it very difficult to do well in any science subject as opined by [7] that there is positive correlation between students' mathematical skills and their exams grades in physics. [6] also said mathematics is not only the language of physics but determines the content and meaning of physical concepts and theories.

Students' interest is very germane to the choice of subject of study and it must not be overlooked in schools as argued by [2] that, if a child is interested in the subject matter, he will learn more. Motivation could be consider being "catalyst" to learning and that is why students must be well motivated by both parents and teachers. According to [2] students must be motivated to learn because children are naturally inclined to be curious and enthusiastic about learning new things. [3] observed that motivation of students in education and the impact on their academic performance is very important to effective learning therefore, students must be well motivated by both parents and teachers.

\section{Conclusion and Recommendations}

In the light of the above findings this study is reaching a conclusion that students' low enrolment in science in secondary schools is caused by lack of qualified science teachers; teacher inability to teach science very well either due to lack of commitment or bad method of teaching. Other causes are lack of science instructional materials: abstract and mathematical nature of science subjects; low interest among students and lack of motivation from both parents and the teachers. It is also important to note that high cost of financing science was equally considered as one of the causes of students' low enrolment in sciences.

However, this conclusion cannot be generalized but specifically applied to the state where the study was carried out. It is therefore suggested that this same study be replicated in other states in Nigeria.

In view of the above conclusion the following recommendations are imperative within the scope of this study to improve students' enrolment in science:

- Stake holders in education must ensure they employ well qualified science teachers into secondary schools. This is necessary because for any student to make any meaningful impact in science this stage must not be trifle with

- Science teachers must from time to time attend seminars, workshops and conferences to update their knowledge of science methods and processes; refresher courses and in-service training must be made compulsory for all science teachers

- Government should always supply science instructional materials to schools and ensure teachers make adequate use of these materials where necessary

- Curriculum planners, textbook writers and science educators should come together and work out modalities to resolve the notion of abstractness of science subjects. This could be through textbooks with good practical illustrations, science curriculum that is based purely on inquiry method of learning; emphasis should also be on community science learning

- Scholarship should always be awarded to any student who is brilliant in science to create interest for others with low or no interest to science and motivate the weak ones

- Parents and teachers should always motivate students to enroll for science courses by exposing them to various career opportunities available in science 


\section{Acknowledgements}

We sincerely thanks all the management of secondary schools who allowed us to use their schools and permitted their students to participate in this study; and also all the authors we cited in the study.

\section{References}

[1] A. Abdullahi. Science Teaching in Nigeria. Ilorin: Author, 1982

[2] A. Hermit. The Role of Motivation in Education. A-Z Education: Motivation 2007; http://contributor.yahoo.com/user/408/a_hermitt.html (access date: August 7th 2013)

[3] A. Tella. The impact of motivation on student's academic achievement and learning outcomes in mathematics among secondary school students in Nigeria. Eurasia Journal of Mathematics, Science \& Technology Education, Vol. 3(2), 2007, pp. 149-159.

[4] A.O. Akanbi. An Investigation into Students' Performance in Senior Secondary School Physics. Journal of Teacher education trends, Vol. 1(1), 2003, pp. 58-64.

[5] B. A. Awolaju, and O. O. Akinloye. Science education in democratized Nigeria: challenges And the way forward. South-West Journal of Teacher Education, Vol. 3, 2010, pp. 615-622

[6] C. Tzanakis On the relation between mathematics and physics in undergraduate teaching. Publication of department of education, university of Crete, Rethymnon

[7] D.E. Meltzer. The relationship between mathematics preparation and conceptual learning gain in physics: A possible "hidden variable" in pre-test scores. Publication Of department of physics and astronomy, Iowa state university, Ames, Iowa, USA, 2002

[8] E.O. Omoesewo .Views of physics teachers on the need to train and retrain Physics teachers in Nigeria, African Research Review, Vol.3 (1), 2009, pp. 314-325

[9] J. B. Awolola. Physics Methodology, book one. Ilorin, Nigeria: the author, 2004

[10] J.K Aina. Challenges and prospects of primary science teaching in Nigeria. Continental Journal of Education Research, Vol. 5(2), 2012, pp. 32-37
[11] J.K Aina, Teaching aids improvisation in the teaching and learning of physics in secondary Schools, 2012; http://www.articlesbase.com/science-articles/teaching-aidsimprovisation-in-the-teaching-and-learning-of-physics-insecondary-schools-5675240.html (access date: August $7^{\text {th }}$ 2013 )

[12] J.K, Aina. Subject Area Specialization-Combination Correlation in Colleges of Education: Effect on Students' Achievement in Physics. Open Journal of Education, Vol.1 (3), 2013, pp. 113-116. DOI: 10.12966/oje.06.06.2013

[13] L. Bamidele. Students' Poor Performance in Physics. A Bane to our Nation's Technological Development. Nigerian Journal of Science Education and Practice. Vol. 2(1), 2004, pp. 174-179

[14] L. N. Besty. The application of community service learning in science education. Asia Pacific Forum on Science Learning and Teaching, Vol. 13(2), 2012, pp. 1-17

[15] M.A, Sheriff B.T Maina,, and Y. Umar. Physics in education and human resources Development. Continental Journal of Education Research, Vol. 4(3), 2012, pp. 23-26

[16] M. Bhowmik, B. Banerjee (ray) and J. Banerjee. Role of pedagogy in effective teaching. Basic Research Journal of Education and Review, Vol. 2(1), 2013, pp.1-5

[17] N. Nguyen, J. Williams and T. Nguyen. The use of ICT in teaching tertiary physics: Technology and pedagogy. AsiaPacific Forum on Science Learning and Teaching, Vol. 13 (2), 2012, pp. 1-19

[18] S.A. Adeyemo. Teaching/ learning physics in Nigerian secondary school: The curriculum transformation, issues, problems and prospects. International Journal of Educational Research and Technology, Vol. 1 (1), 2010, pp.99-111

[19] S.A. Daramola. Research and statistical method in Education for Students and Researchers inTertiary Institutions. Ilorin:Bamitex printing and publishing, 2006

[20] S. N. Osuji. New perspectives in adult education in Nigeria in the $21^{\mathrm{st}}$ century. Journal Of Curriculum and Instruction, Vol. 6(1\&2), 2002, pp. 17-27

[21] S.O Bolaji. Childhood education in a democratized Nigeria: challenges and way forward. South-West Journal of Teacher Education, 3, 340-352.

[22] Z.N. Khan. Need for improvement of teacher education in the new millennium. International Journal of Secondary Education, Vol. 1(2), 2013, pp.4-7. doi: 10.11648j.ijsedu .20130102.11 